\title{
A Note on the Rising Cost of Education in Australia
}

\author{
Second revised version \\ ABBAS VALADKHANI \\ School of Economics and Finance, \\ Queensland University of Technology, \\ Brisbane, Qld 4001 \\ ANDREW C. WORTHINGTON \\ School of Economics and Finance, \\ Queensland University of Technology, \\ Brisbane, Qld 4001 \\ ALLAN P. LAYTON \\ School of Economics and Finance, \\ Queensland University of Technology, \\ Brisbane, Qld 4001
}

Corresponding Author's Address:

Dr Abbas Valadkhani

School of Economics and Finance

Queensland University of Technology

Gardens Point Campus

GPO Box 2434 Qld 4001

Brisbane-Australia

Email: a.valadkhani@qut.edu.au

Tel: $\quad$ 07-3864 1233

Fax: $\quad 07-38641500$

Author Posting. (c) The Authors (2005). This is the author's version of the work. It is posted here for personal use, not for redistribution. The definitive version was published in Economic Papers, 24(2) pp.97-196. 


\section{A Note on the Rising Cost of Education in Australia*}

\section{Abstract}

Human capital, or a better educated labour force, is a major determinant of economic growth and productivity. However, recent trends in the cost of education in Australia may cause growth and productivity to suffer. For example, during the period 19822003 inflation rose on average by 4.4 per cent per annum, whereas the cost of education grew overall on average by 7.8 per cent. This has made education a relatively expensive item among Australian households. This paper compares and contrasts the cost of education in Australia and comparable economies with the cost of other goods and services embedded in the CPI (Consumer Price Index) basket using the latest available quarterly data. Finally, the major determinants of the rising cost of education in Australia are examined. It is found, inter alia, that over the period 19862003 the increasing number of students enrolled at non-governmental primary and secondary schools and the introduction of the Higher Education Contribution Scheme (HECS) were two important determinants of the rising cost of education.

\section{Introduction}

There is a consensus among economists that human capital plays a substantial role in achieving higher economic growth and increased labour productivity. New growth theories identify the channels through which economic growth occurs and how reform processes can stimulate the rate of investment in physical capital, human capital, technological know-how and knowledge capital. Together these factors exert a sustained and positive effect on the long-run growth of the economy (Rebelo, 1991).

\footnotetext{
${ }^{*}$ We wish to acknowledge an anonymous referee and Dr Anne Daly whose constructive inputs and comments considerably improved an earlier version of this article. The usual caveat applies.
} 
For instance, in their seminal work Barro (1991) and Barro and Lee (1994) echoed the importance of human capital as a major determinant of economic growth and productivity. More recently, Valadkhani (2003) found , inter alia, that long-term policies aimed at accelerating the various types of investment in human capital will also improve labour productivity. As higher productivity translates directly into higher per capita income, Australians as a whole benefit from higher standards of health care, education and public welfare. Very recently, Chou (2003, p.397) found that "42 per cent of Australian growth between 1960 and 2000 is attributable to the rise in educational attainment”. Therefore, it is important to monitor the cost and affordability of education through time. However, compared with the price of most other goods and services, it would appear that the cost of education in Australia has been increasing at an alarming rate. Moreover, with similar trends witnessed in both the United Kingdom and the United States, it seems that Australia is not the only developed country that has experienced this phenomenon.

A better educated workforce will almost certainly have higher income in the future and so we do not take issue in this paper with the increasing role of the private funding of educational expenses. One can argue that the indefinite provision of "free" education by the various tiers of government, through collecting taxes from the society as a whole, is neither equitable nor sustainable into the future. However, given the higher income levels for graduates and the positive externality (or public benefits) associated with a better educated workforce for society, costs should desirably be split between the taxpayer and the student in some sort of optimal manner. In the context of higher education, the important point is that students studying in areas yielding substantial social benefits-but perhaps associated with relatively low market incomeshould have access to interest-free, income-contingent loans as well as government 
direct funding for at least some portion of their study cost. However, if their areas of study are highly marketable (e.g. law and medicine), they may have limited access to such loans (King, 2001, p.192). Nevertheless, the funding of schools and universities remains one of the most vigorously debated issues in Australia. It is interesting to note that the total operating revenue of the 40 higher education institutions in 2002 was \$11.6 billion of which 16 per cent was collected through HECS and 41 percent (54 percent in 1997) financed by Commonwealth Government Grants (Department of Education, Science and Training, DEST, 2002, p.3). Similarly, in 1997 the Commonwealth and State Governments altogether funded: (i) up to 95 per cent of revenue for government schools; and (ii) 56 per cent of revenue for non-government primary and secondary schools (Borthwick, 1999, p.1).

Of course, at the outset, it should be noted that purchasing power parity studies indicate services are often more expensive in rich countries than in poor countries (see, inter alia, Dowrick, 2001, and OECD, 2001) and so one might expect a labour intensive service like education to be increasing in relative price as the country grows. More broadly, Baumol (1997) also argues that the rising cost of labour-intensive industries, such as the arts, health care, and education, is inevitable. Price rises in service industries can therefore be expected to be higher on average than the inflation rate for the economy as a whole.

Furthermore, the rising rate of public-sector inflation can be explained by "the low productivity of labour-intensive government activities compared with the relatively capital-intensive private sector” (Fordham, 2003, p.574). More specifically Gundlach and Wößmann (2001) examined changes in the productivity of schooling for six East Asian countries and they concluded that the price of schooling rose more than the price of other labour-intensive services in 1980 to 1994. They contributed the 
rising price of schooling to declining relative productivity of schooling. According to Gundlach and Wößmann, the fading productivity of schooling in East Asian countries relates to a substantial decline in the pupil-teacher ratio.

Therefore, it is important to note that it is quite normal that services such as education probably can be expected to become more expensive for an advanced country such as Australia. However, it nonetheless remains a useful exercise to investigate to what extent the cost of education has been increasing and what may be the possible causes of this rise.

The basic objectives of this brief paper are therefore to: (i) substantiate the extent to which the cost of education has been rising in Australia and internationally; and (ii) determine the major factors contributing to such important phenomena which undoubtedly will have implications for the long-run prosperity of Australia's economy. It is not our intention to delve into alternative policy approaches which attempt to deal with the issue of the most appropriate way to fund the education system. For a detailed account of the literature on the various views on the way in which education at all levels can be financed see Barr (1998), Borthwick (1999), Quiggin (1999), King (2001), Chapman (2001) and Burke and Long (2002), amongst others.

The remainder of this paper is structured as follows: Section 2 makes a crosscountry comparison between the cost of education in Australia and two comparable OECD countries (viz. the U.S and the U.K). Section 3 contrasts the cost of education and the price of other goods and services embedded in the CPI using data during the period 1982-2003. Section 4 examines two important aggregate factors thought to contribute to the rising cost of education during the period 1986-2003. The final section provides some brief concluding remarks. 


\section{The Cost of Education in Australia, the UK and the US}

Based on data from (Australian Bureau of Statistics, ABS, 2003a), Figure 1 shows that the annualised rate of increase in the cost of education, as measured by $\ln (P)_{t^{-}}$ $\ln (P)_{t-4}$, in Australia, the U.K and the U.S has almost always been substantially higher than the rate of inflation. To some extent, this growing gap may be attributed to the difference between the government and private expenses on education as a proportion of GDP compared with public funding alone. Over the period 1992-2001, while the average share of government expenses in GDP was around 4.8 per cent, the share of total expenses (both private and government) in GDP was 5.8 per cent. Overall, the share of private spending on education has increased more on a relative basis through time (ABS, 2003b).

\section{[Figure 1 about here]}

In a similar way an increasing proportion of primary and particularly secondary pupils study at private schools. In 1986 about 30 per cent of secondary pupils were attending private schools, whereas in 2003 this figure reached about 35 per cent. Total enrolments at both primary and secondary private schools rose by 1.7 per cent per annum over the 15 years from 1986 to 2001, compared with a more modest increase of 0.18 per cent annually for government schools (ABS, 2002).

\section{Education Cost vs. the Cost of Other Sub-Groups of the CPI}

As defined in ABS (2003a), the CPI measures changes in the price of a basket of goods and services consumed by metropolitan households in the following eleven broad groups: Food; Alcohol and Tobacco; Clothing and Footwear; Housing; Household Furnishings, Supplies and Services; Health; Transportation; 
Communication; Recreation; Education; and Miscellaneous. It is interesting to note that the weight assigned to Education in the computation of the CPI is just 2.7 per cent of the total household expenditure, whereas the corresponding weights for Alcohol and Tobaccos, and Recreation are approximately 7.4 per cent and 12.3 per cent, respectively.

ABS (2003a) has disaggregated the education sub-group of the CPI into three main sub-categories, viz. Pre-school and Primary education; Secondary education; and Tertiary education. The published data on these sub-groups are available only from June quarter 2000 to September quarter 2003. Table 2 presents the total growth rate and average contribution of various components of the education sub-group of the CPI during the June 2000-September 2003 period. It is obvious that while the cost of Tertiary education increased by 8.6 percent during the period, the corresponding growth rates in both Preschool and Primary education and Secondary education were above 20 percent.

Therefore, to a large extent, and on a relative basis, the increasing cost of education is attributable to the rising expenses in Preschool and Primary education and Secondary education. A small weight assigned to Education in the computation of the CPI can explain the meager average contribution of the three components of the Education sub-group of the CPI during the June 2000-September 2003 period in Table 2. Therefore, the mounting cost of education does not substantially affect the overall rate of inflation.

\section{[Table 2 about here]}

Given that an increasing number of Australian families prefer to send their children to be educated at private schools, one may well argue that the 2.7 per cent weight for education may not fully represent the real world situation. Percival and 
Harding (2003, p.6), for example, estimate that "it will cost the average Australian couple about \$448,000 (in today’s dollars) [March 2002 dollars] to raise two children from birth until the end of their $20^{\text {th }}$ year”. According to their calculation, around 11 per cent (or $\$ 50,000$ ) of the $\$ 448,000$ is spent on education and child care. According to another estimate, "it would cost the average Australian household approximately $\$ 40,000$ to put a child through primary and secondary education (12 years education)” (The Life: The Lifeplan Funds Management Investors Magazine, July 2003, p.5). This does not include indirect costs such as earnings foregone.

Table 3 clearly indicates Education and Alcohol and Tobacco as the two subgroups of the CPI which increased in cost relatively more than the other nine CPI subgroups, and at much the same rate. In terms of annualised growth rates, the cost of Education and Alcohol and Tobacco was almost twice as much as Australia's headline inflation in both pre- and post-inflation targeting eras. Although the increasing relative price of Alcohol and Tobacco is not so much of a societal concern since it can discourage the excessive consumption of these products, the long-run rise in the cost of education is an obvious cause of concern. However, one may argue that the rising cost education may reflect choices of parents to purchase what they deem as a higher quality education for their children in private schools and as such government should not be concerned about it. With the rising cost of education, many students (aged 15 plus) currently may have to spend a considerable amount of time in the work force in order to cover their living expenses and this will involve some unavoidable impacts on their academic performance.

[Table 3 about here]

\section{Two Important Determinants of the Cost of Education in Australia}


Based on the above descriptive analysis, one can further hypothesise that there are at least two principal factors contributing to the rising cost of education in Australia: (i) the ratio of students attending private schools (primary and secondary) to total number of primary and secondary students (PS); and (ii) the introduction of HECS in 1989 which can be captured by an intercept dummy variable denoted by $H E C S$ in our econometric framework. This dummy variable takes on the value of unity in the postHECS period (i.e. 1989-2003) and zero otherwise. ${ }^{1}$ Thus, the following specification is used:

$\ln (P E D U)_{t}=\beta_{0}+\beta_{1} \ln (P S)_{t}+\beta_{2} H E C S_{t}+e_{t}$

where $P E D U$ represents the cost of education index (1996=100), $\ln$ denotes the natural logarithm, $\beta s$ are the long-run static coefficients to be estimated and $e_{t}$ is the error term which is assumed to be white noise and normally distributed.

An important step before estimating equation (1) is to determine the time series properties of the data. This is an important issue since the use of non-stationary data in the absence of the series being cointegrated can result in quite spurious regression results. To this end, two unit root tests, i.e Augmented Dickey-Fuller (ADF) and the Kwiatskowski-Phillips-Schmidt-Shin (KPSS), have been adopted to examine the stationarity, or otherwise, of the time series data.

According to the results of the ADF and KPSS test, both PEDU and $P S$ are I(1), indicating that they become stationary after first differencing. Thus in terms of the order of integration, equation (1) is a balanced equation. The unit root test results have not been reported here but they are available from the authors upon request. It should be noted that there are only 18 available annual observations in the sample

\footnotetext{
${ }^{1}$ It is worth mentioning that as a result of the introduction of HECS most graduates carry student loans of between $\$ 11000$ to $\$ 30,000$ even before they find a full time job (Sydney Morning Herald, Growing price of education may well cost us all a place in the sun, January 17 2003).
} 
under investigation (1986-2003), and so the unit root test and cointegration results should not be taken too seriously since the tests are most appropriate for large samples. However, common sense and visual inspection of the data suggest the data are certainly not $\mathrm{I}(0)$.

On the assumption that all the variables in equation (1) are I(1), the EngleGranger two-step procedure can be used to examine if this equation represents a longterm relationship. There is a very strong positive correlation coefficient $(+0.981)$ between $P S$ and $P E D U$. Based on this observation, we expect that $\beta_{1}>0$. The empirical econometric results for equation (1) are presented below using the OLS estimation method and annual time series data from 1986 to 2003.

$$
\begin{aligned}
& \ln \left(P E D U_{t}\right)=10.239+4.839 \ln \left(P S_{t}\right)+0.280 H E C S_{t} \\
& t: \quad(21.2) \quad(13.2)
\end{aligned}
$$

As seen from the above model, all the estimated coefficients are statistically significant at the 1 per cent significance level, and have the expected theoretical signs. This equation also performs extremely well in terms of goodness-of-fit statistics. The adjusted $R^{2}$ is as high as 0.963 and the overall $F$ test rejects the null hypothesis at the 1 per cent level. Based on these results, one can argue that in the long-term, one per cent increase in $P S$ can result in more than 4.8 per cent increase in the cost of education index. In terms of the magnitude of the estimated HECS coefficient, the above results indicate that the introduction of $H E C S$, on average, has increased the intercept of the education sub-component index of the CPI.

Based on the estimated coefficients, one can argue that, ceteris paribus, the increasing number of students enrolled at non-governmental schools (primary and secondary) and also the introduction of HECS have significantly and positively contributed to the rising cost index of education in Australia over the last 
two decades. It should be noted that the two variables (PEDU and $P S$ ) in equation (1) are $\mathrm{I}(1)$, and the resulting residuals were found to be $\mathrm{I}(0$.

\section{Concluding Remarks}

The present paper employs descriptive statistics and parametric analysis to examine the rising cost of education in Australia. In common with experiences in comparable OECD economies, the cost of household education expenditure has been rising faster than the overall rate of inflation and paradoxically for the most part as fast or faster than leading economic 'sins' (Alcohol and Tobacco). Such trends are likely to continue in the future, and perhaps even accelerate, with the increasing proportion of primary and secondary students being educated at non-government schools and the liberalisation of contribution charges and full fee-paying quotas in the recent tertiary education reforms.

At first impression, such developments appear to pose potentially adverse impacts on human capital investment in Australia and, in turn, on economic growth and labour productivity. However, it should be remembered that the cost drivers of education in Australia are, in some part, reflective of households' choices concerning education. These include the choice between private and public primary and secondary education in the present and, in the future, careful household choices concerning tertiary courses, institutions and their varying fee structures. Present policy developments in Australia regarding university fees will ensure that the cost of education in Australia, along with its share of household expenditure, will continue to rise in coming years. 


\section{References}

Australian Bureau of Statistics (2003a), Consumer Price Index, cat. no. 6401.0, ABS, Canberra.

Australian Bureau of Statistics (2003b), Australian Social Trends (Education and Training: National summary tables), ABS, Canberra.

Barr, N. (1998), Higher Education in Australia and Britain: What Lessons? Australian Economic Review, 31(2), pp.179-88.

Barro, R. J. (1991), 'Economic Growth in a Cross Section of Countries', Quarterly Journal of Economics, 106(2), pp. 407-43.

Barro, R. J. and Lee, J.W. (1994), 'Sources of Economic Growth,' CarnegieRochester Conference Series on Public Policy.

Baumol, W.J. (1997), Baumol's Cost Disease: The Arts and Other Victims, (Baumol, W.J. and Towse, R., eds.), Edward Elgar, Northampton, Mass.

Borthwick, S. (1999), Overview of Student Costs and Government Funding in PostCompulsory Education and Training, DEST: Research and Evaluation Branch, Canberra.

Burke, G. and Long, M. (2002), The Evolution of School Funding: the ACT and Australia: Paper prepared for the Inquiry into ACT Education Funding, Centre for the Economics of Education and Training, Monash University, Melbourne.

Chapman, B. (2001), Australian Higher Education Financing: Issues for Reform, Australian Economic Review, 34(2), pp.195-204.

Chou, Y.K. (2003) The Australian Growth Experience, 1960-2000: Human Capital, R\&D or Steady-State Growth? Australian Economic Review, 36(4), pp.397-414.

Department of Education, Science and Training (2002), Finance 2002: Selected Higher Education Statistics, Higher Education Group, Canberra.

Dowrick, S. (2001), True International Income Comparisons: Correcting for Bias in Fixed Price Measures and Exchange Rate Measures, the Economic Measurement Group Workshop, 30 ${ }^{\text {th }}$ March, 2001, University of New South Wales.

Fordham, B.O. (2003), The Political and Economic Sources of Inflation in the American Military Budget, Journal of Conflict Resolution, 47(5), pp. 574-93.

Gundlach, E. and Wößmann, L. (2001), The Fading Productivity of Schooling in East Asia, Journal of Asian Economics,12(3), pp. 401-17.

King, S.P. (2001), The Funding of Higher Education in Australia: Overview and Alternatives, Australian Economic Review, 34(2), pp.190-4. 
OECD (2001), Problem Areas in Calculating Times Series of PPPs, OECD, Paris.

Percival, R. and Harding, A. (2003) The Costs of Children in Australia Today, Paper Presented at the Australian Institute of Family Studies Conference, 13 February 2003, Melbourne.

Quiggin, J. (1999), Human Capital Theory and Education Policy in Australia, Australian Economic Review, 32(2), pp.130-44.

Rebelo, S. (1991), Long-Run Policy Analysis and Long-Run Growth, Journal of Political Economy, 99(3), pp. 500-21.

Valadkhani, A. (2003), An Empirical Analysis of Australian Labour Productivity, Australian Economic Papers, 42(3), pp.273-291. 
Figure 1: Inflation Rate and the Growth Rate of Cost of Education in Australia, the UK and the US
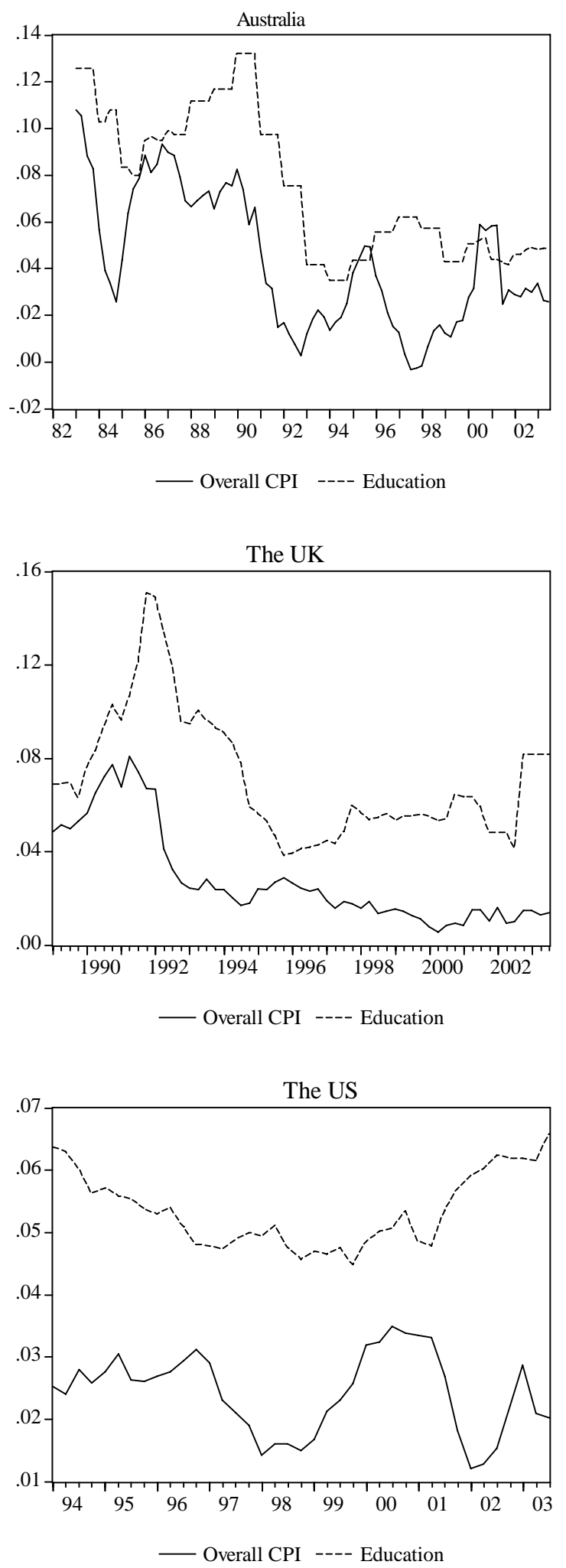

Source: ABS (2003), Consumer Price Index, cat. 6401.0.

(2) National Statistics online database: http://www.statistics.gov.uk/StatBase

(3) http://www.economagic.com 
Table 2: Growth Rate and Average Contribution of Various Components of the Education Sub-Group of the CPI to the Aggregate CPI During the June 2000September 2003 Period

\begin{tabular}{lccc}
\hline \multicolumn{1}{c}{ Description } & $\begin{array}{c}\text { Preschool and primary } \\
\text { education }\end{array}$ & $\begin{array}{c}\text { Secondary } \\
\text { education }\end{array}$ & $\begin{array}{c}\text { Tertiary } \\
\text { education }\end{array}$ \\
\hline $\begin{array}{l}\text { Total growth rate (\%) } \\
\text { Average contribution to the } \\
\text { aggregate CPI (index points) }\end{array}$ & 20.1 & 20.9 & 1.645 \\
\hline
\end{tabular}

Source: ABS (2003a), Consumer Price Index, cat. no. 6401.0, Table 7J. 
Table 3: Annualised Average Growth Rate for Various Sub-Groups of the CPI, Australia

\begin{tabular}{|c|c|c|c|c|}
\hline \multirow{2}{*}{ CPI Groups } & \multicolumn{2}{|c|}{ 1983:q1-2003:q3 } & \multicolumn{2}{|c|}{ 1993:q1-2003:q3 } \\
\hline & $\begin{array}{l}\text { Growth } \\
\text { rate }\end{array}$ & Rank & Growth rate & Rank \\
\hline Alcohol and tobacco & 0.068 & 2 & 0.053 & 1 \\
\hline Education & 0.075 & 1 & 0.048 & 2 \\
\hline Miscellaneous & na & & 0.045 & 3 \\
\hline Health & na & & 0.034 & 4 \\
\hline Food & 0.045 & 3 & 0.031 & 5 \\
\hline Transportation & 0.044 & 4 & 0.023 & 6 \\
\hline Recreation & na & & 0.020 & 7 \\
\hline Housing & 0.039 & 5 & 0.018 & 8 \\
\hline Household furnishings, supplies and services & 0.033 & 6 & 0.011 & 9 \\
\hline Clothing and footwear & 0.031 & 7 & 0.005 & 10 \\
\hline Communication & 0.020 & 8 & 0.002 & 11 \\
\hline All groups & 0.043 & - & 0.025 & - \\
\hline
\end{tabular}

Source: ABS (2003a), Consumer Price Index, cat. 6401.0. TABLE 3B.

Note: The annualized growth rate is calculated by taking the average of $\ln (P)_{\mathrm{t}}-\ln (P)_{\mathrm{t}-4}$ in the corresponding time periods. 
